\title{
Título da página electrónica: Conselho para o Desenvolvimento da Pesquisa em Ciências Sociais em África (CODESRIA)
}

URL: http://www.codesria.org

\section{Margarida Filipe Gomes}

\section{(2) OpenEdition \\ Journals}

Edição electrónica

URL: https://journals.openedition.org/rccs/711

DOI: $10.4000 /$ rccs.711

ISSN: 2182-7435

\section{Editora}

Centro de Estudos Sociais da Universidade de Coimbra

\section{Edição impressa}

Data de publição: 1 março 2008

Paginação: 219-220

ISSN: 0254-1106

Refêrencia eletrónica

Margarida Filipe Gomes, «Título da página electrónica: Conselho para o Desenvolvimento da Pesquisa em Ciências Sociais em África (CODESRIA)», Revista Crítica de Ciências Sociais [Online], 80 | 2008 , publicado a 01 outubro 2012, consultado a 10 fevereiro 2023. URL: http://journals.openedition.org/ rccs/711 ; DOI: https://doi.org/10.4000/rccs.711

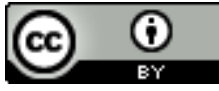

Creative Commons - Atribuição 4.0 Internacional - CC BY 4.0

https://creativecommons.org/licenses/by/4.0/ 


\title{
Espaço Virtual
}

\section{Título da página electrónica: Conselho Latino-Americano de Ciências Sociais (CLACSO)}

\author{
URL: http://www.clacso.org
}

O site do Conselho Latino-Americano de Ciências Sociais (CLACSO) apresenta uma instituição não-governamental consultora da UNESCO. Criada em 1967, agrega actualmente 216 centros de investigação e programas de ensino de graduação e pós-graduação em ciências sociais de 21 países da América Latina e Caraíbas, tendo também como membros um centro em Espanha e um em Portugal (Centro de Estudos Sociais). Elege como objectivos a promoção e desenvolvimento da investigação e o ensino das ciências sociais, o fortalecimento do intercâmbio entre instituições e investigadores de dentro e fora da região e uma adequada difusão dos conhecimentos produzidos por cientistas sociais, organizações da sociedade civil e movimentos sociais. O site divulga e difunde uma ampla

variedade de informação respeitante às actividades concretas desenvolvidas pela organização. Livros, revistas, uma agenda actualizada e uma biblioteca virtual são apenas alguns dos recursos apresentados. Apresenta com especial destaque a Cátedra Florestan Fernandes, criada em 2000 como um espaço académico de análise das transformações, teorias e problemáticas características dos países da América Latina e Caraíbas, e o programa de intercâmbio Sul/Sul que revitalizou o intercâmbio e a cooperação entre os cientistas e líderes sociais da África, Ásia e da América Latina e Caraíbas, no intuito de fomentar a produção de um pensamento crítico a partir do Sul, construído com base no conhecimento das realidades regionais desta parte do mundo.

\section{Título da página electrónica: Conselho para o Desenvolvimento da Pesquisa em Ciências Sociais em África (CODESRIA) URL: http://www.codesria.org}

Fundado em 1973, o CODESRIA tem a sua sede em Dakar (Senegal). O site apresenta uma organização pan-africana pioneira e líder no domínio das ciências sociais, entendidas num sentido amplo, assumindo como missão a luta contra a fragmentação da pesquisa e da produção de conhecimentos através da criação de redes temáticas de investigação capazes de ultrapassar as barreiras regionais, linguísticas e disciplinares. O CODESRIA promove uma abordagem holística das vivências históricas e contemporâneas por via do incentivo a uma interdisciplinaridade assente num conjunto de tradições e abordagens capaz de integrar as diferentes perspectivas em análise sem o privilégio directo de nenhuma delas. Com o propósito último de fazer ouvir e dar visibilidade à produção intelectual dos investigadores africanos na cena internacional, apresenta um programa de bolsas que promove a excelência intelectual ao nível do mestrado, doutoramento e pós-doutoramento. A disseminação dos resultados destas pesquisas é feita quer por via das numerosas publi- 
cações promovidas pelo CODESRIA, quer pelo próprio site, que disponibiliza uma enorme base que inclui revistas, monografias e documentos de trabalho. Apesar de se dirigir fundamentalmente a parceiros africanos, o CODESRIA desenvolve também uma política de redes com outros continentes, nomeadamente com a CLACSO
- Conselho Latino-Americano de Ciências Sociais; com a APISA - Asian Political and Internacional Studies Association e a EADI - European Association of Development Research and Training Institutes.

Margarida Gomes

margarida@ces.uc.pt

\section{Título da página electrónica: Projecto AmaZone - A Onça, a diferença e o pensamento ameríndio: uma construção contra-hegemónica e colectiva URL: http://amazone.wikia.com/wiki/P\%C3\%A1gina_principal\#Cita.C3. A7.C3.B5es_.28no_original.29}

Desde 2005, está em curso na Internet uma experiência inovadora de construção híbrida e colectiva de um pensamento filosófico baseado na vida e experiências dos povos indígenas da América do Sul e na agregação de estudos sobre e com eles. Por iniciativa do etnólogo Eduardo Viveiros de Castro, do Museu Nacional do Rio de Janeiro, o Projecto AmaZone, conforme apresentaçao do próprio site, "é a migração para o formato wiki de um estudo intitulado $A$ Onça e a Diferença, em preparação desde 1997. Essa obra versa sobre os pressupostos do pensamento indígena americano. Seu foco é a imaginação conceitual nas culturas nativas da Amazônia, e sua abordagem é antropológica”. Sem se prender num pensamento "latino-americano" essencialista, o AmaZone propõe-se (e con- segue) combater a "produção de (des)conhecimento" e evidenciar a emergência de um pensamento "ameríndio", um dos tantos silenciados e tornados invisíveis pelo colonialismo, resultado de uma "construção da natureza como algo exterior à sociedade - uma construção estranha aos povos com que os europeus entraram em contacto". A iniciativa de Viveiros de Castro insere-se no campo "contra-hegemónico", enquanto projecto de livro que o autor decide abrir a um público-parceiro amplo, desdobrando a própria escrita num "pensamento-nómada [...] pensamento-outro, que louva a vida, que resiste às determinações da falta”.

Túlio de Souza Muniz tuliomuniz2000@yahoo.com.br 